\title{
PENGARUH SISTEM AKUNTANSI TERHADAP KEMAMPUAN MAHASISWA PENDIDIKAN AKUNTANSI UNTUK MENJADI PEMIMPIN DALAM ORGANISASI
}

\author{
Oleh: Asmuni \\ (UNIVERSITAS PGRI PALEMBANG) \\ Asmuni6006@gmail.com
}

\begin{abstract}
Abstrak-Sistem akuntansi merupakan formulir-formulir dan catatan-catatan, prosedur-prosedur serta alat-alat yang digunakan untuk mengolah data mengenai kesatuan ekonomis dengan tujuan untuk menghasilkan umpan balik dalam bentuk laporan-laporan yang oleh pihak manajemen untuk mengawasi organisasi, dan bagi pihak lain yang berkepentingan dan lembaga-lembaga pemerintah untuk menilai hasil operasional satuan organisasi. Jadi jelaslah bahwa tujuan sistem akuntansi suatu organisasi disusun untuk mengidentifikasikan, merakit, mencatat dan melaporkan berbagai informasi yang berguna untuk pihak intern dan ekstem organisasi. Mahasiswa yang dapat memahaminya denga baik maka mereka masuk organisasi manapun akan dapat mengerjakan apapun yang menjadi tanggung jawab mereka.
\end{abstract}

Kata Kunci: Sistem Akuntansi, pemimpin dan organisasi

Abstract-The accounting system is forms and records, procedures and tools used to process data regarding economic unity with the aim of producing feedback in the form of reports by management to oversee the organization, and for other parties who interest and government agencies to assess the operational results of organizational units. So it is clear that the purpose of an organization's accounting system is arranged to identify, assemble, record and report various information that is useful for internal parties and external organizations. Students who can understand it well then they enter any organization will be able to do whatever is their responsibility.

Keywords: Accounting Systems, leaders and organizations

\section{PENDAHULUAN}

\section{A. Latar Belakang Masalah}

Perkembangan pendidikan yang baik akan menjadikan suatu Negara, mampu bertahan di Era Globalisasi serta dapat mengurangi resiko terkena krisis ilmu pengetahuan dan teknologi. Pendidikan mempunyai peran yang sangat penting dalam pembangunan mental dan sipiritual karena pendidikan berperan sebagai sebagai modal utama untuk bangkit dari ketertinggalan dari negara-nagara lain yang sudah jauh meninggalkan kita.

Indonesia sebagai negara yang sedang berkembang, saat ini sedang 
giatgiatnya mengadakan pembangunan disegala bidang demi tercapainya tujuan pembangunan nasional dan mengejar ketinggalan dari negara lain. Tujuan pembangunan nasional hanya dapat tercapai bila ada partisipasi dari seluruh rakyat Indonesia dengan kata lain pembangunan nasional merupakan tanggung jawab seluruh rakyat Indonesia, bukan hanya tanggung jawab pemerintah saja.

Adapun tujuan pembangunan nasional yang hendak dicapai oleh seluruh rakyat Indonesia tersebut adalah terwujudnya masyarakat Indonesia yang damai, demokratis, berkeadilan, berdaya saing, maju dart sejahtera, dalam wadah Negara Kesatuan Republik Indonesia (NKRI) yang didukung oleh manusia Indonesia yang sehat, mandiri, beriman, bertakwa, berakhlak mulia, cinta tanah air, berkesadaran hukum dan lingkungan, menguasai ilmu pengetahuan dan teknologi, memiliki etos kerja yang tinggi dan disiplin. Maksud dari tujuan pembangunan nasional yaitu masyarakat yang adil dan makmur itu adalah masyarakat Indonesia yang dapat menikmati seluruh pembangunan termasuk pembangunan umumnya di bidang ekonomi dan khususnya dibidang pendidikan.

Dewasa ini usaha ke arah pengembangan dunia pendidikan maju dengan pesat, ini dapat dilihat dengan semakin gencarnya pemerintah dalam usaha peningkatan mutu di sektor pendidikan, dapat dilihat dengan semakin maraknya sekolah-sekolah unggulan dan sekolah-sekolah bertarap international melihat kejadian ini tentunya organisasi sekolah haruslah lebih solid dan tertata dengan baik karna sekolah-sekolah yang unggulan dan sekolah-sekolah bertarap international harus mempunyai manajemen dan organisasi yang baik untuk mengelola sekoalah-sekolah tersebut. Pengetahuan Sistem Akuntansi sangat dibutuhkan oleh setiap manusia yang selalu berada dalam lingkungan terutama lingkungan organisasi yang tersturuktur seperti halnya organisaasi perusahaan, seperti perusahaan jasa, perusahaan dagang, perusahaan industry, yayasan, BUMN, dan dunia pendidikan misalnya sekolah-sekolah mulai dari tringkat Sekolah Dasar, Sekolah Menengah Pertama, Sekolah Menengah Atas samapai dengan perguruan tinggi. Mahasiswa yang ada prodi pendididkan sangat beruntung mendapat materi perkuliahan sistem akuntansi dan ini akan memnjadi modal mereka nantinya untuk terjun kemasyarakat dan disekolah dimana mereka mengajar sesuai dengan profesi yang akan mereka geluti dan dengan ilmu sistem akuntansi mereka akan siap untuk menjadi pemimpin professional disekolah disekolah mereka mengajar. 


\section{B. Permasalahan}

Berdasarkan uraian diatas maka masalah yang akan dibahas dalam tulisan ini adalah "apakah sistem akuntansi berpengaruh terhadap kemampuan seseorang untuk menjadi pemimpin yang profisional dalam organisasi."

\section{Tujuan}

Adapun tujuan tulisan ini Untuk mengetahui pengarus sistem akuntansi terhadap kemampuan seseorang untuk menjadi pemimpin yang profisional dalam organisasi.

\section{PEMBAHASAN}

\section{A. Sistem Akuntansi}

Sistem adalah kumpulan dari elemen-elemen atau komponen tertentu baik pisik maupun non pisik yang saling berhubungan satu sama lain dan bekerjasama secara harmonis untuk mencapai tujuan. Definisi lain sistem merupakan jaringan prosedur yang saling berhubungan satu sama lain untuk melaksanakan aktivitas organisasi dalam perusahaan.

Organisasi menggantungkan diri pada sistem akuntansi untuk mempertahankan kemampuan kompetisi. Produktivitas suatu hal yang penting agar tetap kompetitif dapat ditingkatkan melalui sistem akuntansi yang lebih baik. Akuntansi sebagai suatu sistem akuntansi mengidentifikasikan, mengumpulkan dan mengkomunikasikan informasi ekonomi mengenai suatu badan usaha kepada beragam orang.

Informasi akuntasi merupakan bagian terpenting dari seluruh informasi yang diperlukan oleh manajemen. Informasi akuntansi terutama berhubungan dengan data keuangan dari suatu organisasi. Agar data yang ada dapat dimanfaatkan oleh pihak manajemen maupun oleh pihak luar organisasi. Maka data tersebut harus disusun dalam bentuk yang. sesuai. Untuk itulah diperlukan suatu sistem mengatur arus dan mengelola data akuntansi dalam organisasi yaitu sistem akuntansi.

Agar informasi tersebut dapat tersusun dengan baik, maka dirangkailah dalam suatu sistem. yang nantinya dapat membentuk suatu kesatuan yang utuh dan saling behubungan. Sistem informasi yang relevan mempunyai karakteristik yaitu tumbuh dan berkembang sepanjang masa, mempunyai jaringan arus informasi. melaksanakan tugas-tugas yang perlu sehubungan dengan pengolahan data, menyediakan berbagai informasi kepada pemakai untuk berbagai tujuan dan menggunakan berbagai sumber daya yang ada.

Pengertian atau definisi sistem akuntansi menurut "Nugroho widjadjanto (2001:4) adalah :

"Susunan berbagai dokumen, atas komunikasi, tenaga pelaksana dan berbagi laporan yang di disain untuk mentransformasikan data 
keuangan menjadi informasi keuangan".

Kemudian "George $H$.

Bodnar. Williams. S. Hopwood (2003:1) menyatakan bahwa sistem informasi akuntansi adalah :

"Kumpulan sumber daya. seperti manusia dan peralatan, yang diatur untuk mengubah data menjadi informasi keuangan".

Menurut Zaki baridwan (2007:

4), Sistem akuntasi adalah :

"Suatu komponen organisasi yang mengumpulkan. menggolongkan, pengolahan.

perencanaan dan mengkomunikasikan informasi keuangan yang relevan untuk pengambilan keputusan kepada pihak-pihak luar perusahaan (seperti inspeksi pajak, investor dan kegiatan kreditur dan pihak-pihak internal terutama manajemen)".

Sistem akuntansi merupakan salah satu sistem informasi yang penting dalam perusahaan, sekolah atau yayasan namun bukan merupakan keseluruhan atau satusatunya sistem informasi yang formal.

Adapun tujuan awal dari sistem akuntansi adalah mengenali transaksi-transaksi yang akan diproses oleh sistem. Seluruh pertukaran keuangan dengan entitasentitas lain yang harus direfleksikan dalarn laporan keuangan organisasi.

Dari pengertian yang dijabarkan sebelumnya maka dapat diambil suatu kesimpulan bahwa sistem akuntansi adalah suatu komponen organisasi yang terdiri dari manusia dan peralatan yang mengolah data transaksi untuk mendukung manajer dalarn mengambil keputusan.

\section{B. Pemimpin}

Kepemimpinan adalah masalah yang utama dalam hidup dan kehidupan ummat manusia, oleh sebab itu ummat manusia selalu membutuhkan pemimpin, sebab untuk mencapai suksesnya sebuah tujuan harus ada pemimpin. Sebagaimana hal yang telah dilakukan para ilmuan yang melakukan study dan penelitian masalah pemimpin dan kepemimpinan. Dan para sarjana telah memberikan berbagai definisi mengenai pemimpin dan kepemimpinan, dengan menonjolkan satu atau beberapa aspek tertentu sesuai dengan ide pencetus definisi tersebut beserta interpretasinya.

Kepemimpinan adalah merupakan cabang dari kelompok ilmu administrasi, khususnya ilmu adminisaatrasi Negara. Sedangkan ilmu administrasi adalah salah satu cabang dari ilmu-ilmu sosial, dan merupakan salah satu perkembangan dari filsafat. Dalam kepemimpinan terdapat hubungan antar manusia; yaitu hubungan mempengaruhi (dari pemimpin), dan hubungan kepatuhan-kepatuhan para pengikut/bawahan karena dipengaruhi oleh kewajiban 
pemimpin. Para pengikut terkena pengaruh kekuatan dari pemimpinya, dan bangkitlah secara spontan rasa ketaatan kepada pemimpin.

Munculnya seorang pemimpin ditimbulkan oleh bermacam-macamam hal, secara garis besar dapat disebutkan dalam tiga teori, yiatu :

1. Teori Genetis. Teori ini menyatakan sebagai berikut :

a. Pemimpin itu tidak dibuat, akan tetapi lahir jadi pemimpin oleh bakat-bakat alami yang luar biasa sejak lahirnya.

b. Dia ditakdirkan lahir menjadi pemimpin dalam situasi dan kondisi yang bagaimanapun juga.

2. Teori Sosial (Lawan teori genetic), yang menyatakan sebagai bertikut:

a. Pemimpin itu harus disiapkan, dididik, dan dibentuk, tidak terlahirkan begitu saja.

b. Setiap orang bisa menjadi pemimpin, melalui usaha penyiapan dan pendidikan, serta didorong oleh kemauan sendiri.

3. Teori Ekologis atau Sintesis (muncul sebagai reaksi dari kedua teori tersebut lebih dahulu). Teori ini menyatakan bahwa Seseorang akan sukses menjadi seorang pemimpin, bila sejak lahirnya telah memiliki bakat-bakat kepemimpinan, dan bakat-bakat ini sempat dikembangkan melalui pengalaman dan usaha pendidikan; juga sesuai dengan tuntutan lingkungan/ekologisnya.

Kepemimpinan tidak harus dibatasi oleh aturan-aturan atau tata krama birokrasi, kepemimpinan tidak harus diikat terjadi dalam suatu organisasi tertentu, melainkan kepemimpinan bisa terjadi dimana saja, asalkan seseorang menunjukkan kemampuannya mempengaruhi perilaku orang-orang lain ke arah tercapainya suatu tujuan tertentu, tanpa harus diikat organisasi, dan tidak dibatasi oleh jalur komunikasi struktural, melainkan bisa menjalin jalur net work yang merembes secara luas melampaui jalur structural, seperti Kepemimpinan Informal.

Apabila kepemimpinan itu dibatasai oleh tata krama birokrasi atau dikaitkan terjadinya dalam suatu organisasi tertentu, maka dinamakan manajemen. Fungsi-fungsi seperti perencanaan, pengorganisasian, pelaksanaan dan pengawasan menjadi perhatian utama yang harus dilaksanakannya. Fungsi-fungsi ini relevan dalam setiap jenis organisasi dan setiap tingkat hirarki manajemen yang ada dalam organisasi tersebut.

$$
\text { Selain dikenal adanya }
$$

Pemimpin dan Kepemimpinan untuk mencapai suatu tujuan tertentu, dikenal juga istilah Manajemen dan Manejer yang lebih terorganisir dan tertata rapi. Perkembangan Manajemen sangat erat kaitannya dengan perkembangan administrasi di Negara-negara maju sebagai akibat revolusi industri. Kebutuhan 
industri yang mengharapkan laba (keuntungan yang banyak) menuntut perbaikan dan peningkatan kinerja melalui berbagai study dan penelitian.

Penelitian dilakukan terhadap model-model peningkatan kerja, pendayagunaan sumber daya, (tenaga, dana, sarana dan prasarana), metode, dan sistem kerja. Sasaran akhir adalah efisiensi dan efektivitas kerja, sehingga keuntungan menjadi lebih besar. Dalam study dan penelitian ini sangat diperhatikan bagaimana bisa menggerakkan orang lain agar merasa senang bekerja. Dengan pandangan tersebut lahirlah berbagai macamam terori dan pengertian tentang manajemen.

Hal seperti ini juga berlaku dalam masalah kepemimpinan, ada manusia yang terbatas kemampuannya untuk memimpin pada satu pihak, tetapi pada pihak lain ada manusia yang mempunyai kelebihan kemampuan untuk memimpinan. Dalam suasana yang seperti inilah timbul apa yang disebut dengan kebutuhan akan pemimpin dan kepemimpinan.

Oleh karena itulah maka kita tidak perlu heran apabila kita mengikuti tulisan-tulisan dan atau uraian-uraian tentang kepemimpinan selalu memberikan gambaran yang ideal tentang kepemimpinan dan berakhir dengan kesenangan. Hal ini dapat dimengerti, karena manusia sangat membutuhkan kepemimpinan itu. Dan bahkan tidak berlebihan apabila disebutkan bahwa dari waktu ke waktu kepemimpinan menjadi tumpuan harapan dari seluruh manusia.

Untuk menunjukkan betapa pentingnya masalah kepemimpinan ini, ada satu pendapat yang sangat ekstrim yang menyatakan bahwa, Dunia atau ummat manusia di dunia ini pada hakikatnya hanya ditentukan oleh beberapa orang saja, yakni yang berstatuys sebagai pemimpin. Dan ada juga ungkapan Melayu yang sejalan dengan ini yaitu, Jika gajah sama gajah berkelahi, maka pelanduk mati di tengah-tengah. Kedua ungkapan ini secara tidak langsung menyatkan bahwa masalah pemimpin dan kepemimpinan adalah masalah yang sangat utama dalam hidup dan kehidupan ummat manusia.

\section{Organisasi}

Pengertian organisasi telah banyak disampaikan para ahli, tetapi pada dasarnya tidak ada perbedaan yang prinsip, dan sebagai bahan perbandingan akan disampaikan beberapa pendapat sebagai berikut:

James D. Mooney mengatakan bahwa : "Organization is the form of every human association for the attainment of common purpose" (Organisasi adalah setiap bentuk kerjasama untuk mencapai tujuan bersama)

Menurut Dimock, Organisasi adalah: "Organization is the systematic bringing together of 
interdependent part to form a unified whole through which authority, coordination and control may be exercised to achive a given purpose" organisasi adalah perpaduan secara sistematis daripada bagian-bagian yang saling ketergantungan/berkaitan untuk membentuk suatu kesatuan yang bulat melalui kewenangan, koordinasi dan pengawasan dalam usaha mencapai tujuan yang telah ditentukan).

Dari beberapa pengertian organisasi di atas, dapat disimpulkan bahwa setiaporganisasi harus memiliki tiga unsur dasar, yaitu :

1. Orang-orang (sekumpulan orang),

2. Kerjasama,

3. Tujuan yang ingin dicapai,

Dengan demikianorganisasi merupakan sarana untuk melakukan kerjasama antara orang-orang dalam rangka mencapai tujuan bersama, dengan mendayagunakan sumber daya yang dimiliki.

\section{Ciri-Ciri Organisasi}

Seperti telah diuraikan di atas bahwa organisasi memiliki tiga unsur dasar, dan secara lebih rinci organisasi memiliki ciri-ciri sebagai berikut :

a. Adanya suatu kelompok orang yang dapat dikenal dan saling mengenal

b. kegiatan yang berbeda-beda, tetapi satu sama lain saling berkaitan (interdependent part) yang merupakan kesatuan kegiatan c. Tiap-tiap orang memberikan sumbangan atau kontribusinya berupa; pemikiran, tenaga, dan lain-lain, Adanya kewenangan, koordinasi dan pengawasan. Adanya tujuan yang ingin dicapai.

\section{Prinsip-Prinsip Organisasi}

Prinsip-prinsip organisasi banyak dikemukan oleh para ahli, salah satunya A.M. Williams yang mengemukakan pendapatnya cukup lengkap dalam bukunya "Organization of Canadian Government Administration" (1965), bahwa prinsipprinsip organisasi meliputi :

1. Prinsip bahwa Organisasi Harus Mempunyai Tujuan yang Jelas,

2. Prinsip Skala Hirarkhi,

3. Prinsip Kesatuan Perintah,

4. Prinsip Pendelegasian Wewenang,

5. Prinsip Pertanggungjawaban,

6. Prinsip Pembagian Pekerjaan,

7. Prinsip Rentang Pengendalian,

8. Prinsip Fungsional,

9. Prinsip Pemisahan,

10. Prinsip Keseimbangan,

11. Prinsip Fleksibilitas,

12. Prinsip Kepemimpinan.

\section{Kesimpulan}

Setia orang akan sepakat
bahwa membahas masalah
kepemimpinan merupakan topic
yang sangat menarik dan mendapat
perhatian dari semua orang, masalah
kepemimpinan dapat kita lihat dari
berbagai sudut pandang sesuai 
dengan spesialisasi atau keinginan seseorang. Oleh sebab itu maka kita tidak perlu heran apabila masalah kepemimpinan dari waktu ke waktu mendapat perhatian semua orang terutama para ahli di bidangnya.

Dari pernyataan ini harus diakui bahwa kepemimpinan dibutuhkan oleh seluruh ummat manusia, sebab dalam setiap diri manusia terdapat kelebihankelebihan dan juga kekurangankekurangan. Seseorang memiliki kelebihan tertentu tetapai pada saat yang bersamaan dia juga memiliki kekurangan tertentu. Kelebihannya itu barang kali tidak ada pada diri orang lain, sehingga dia dapat melengkapinya, tetapi dia juga memiliki kekurangan tertentu, sehingga orang lain dapat melengkapinya seperti halnya sekumpulan orang-orang didalam organisasi.

Kaitannya dengan sistem akuntan yang sering dibut dengan organisasi permulir, dari sekumpulan orang-orang yang ada dalam organisasi yang melakukan pencatatan-pencatatan atas beberapa transaksi, dan hal itu akan menuntun orang-orang tersebut menjalankan tugas mereka sesuai dengan apa yang menjadi tanggung jawabnya.

Seorang pemimpin dengan perencanaan yang matang dan dengan memahami sistem akuntansi akan lebih mudah untuk melaksanakan tugasnya dan lebih mudah dalam pelaksanaan pengontrolan pada organisasi yang dipimpinnya dengan mengorganisir formulir-formulir yang mengalir disetiap bafian-bagian yang terkait dan menuntut bawahan-bawahannya akan lebih berdisiplin.

\section{Saran-saran}

Mengingat manfaat ilmu akuntansi secara umum dan khususnya sistim Akuntansi bagi mahasiswa yang ingin memilih jurusaan tentunya sangat bijak memilih jurusaan atau prodi akuntansi, karna ilmunya dapat digunakan untuk kehidupan sehariharri dan dapat dimanfaatkan sampai hari tua dimasa pensiun dengan cara membuka usaha kecil atau pun usaha secara besar-besaran sesuai dengan kemampuan modal yang kita miliki.

\section{DAFTAR PUSTAKA}

Alwi, Syafaruddin. 2001, Manajemen Sumber Daya Manusia, Strategi Keunggulan Kompetitif, Badan Penerbit Fakultas Ekonomi, Yogyakarta.

Baridwan, Zaki. 1998. Sistem Akuntansi Penyusunan Prosedur dan Metode. Yogyakarta: BPFE.

Fattah, Nanang, 2006. Landasan Manajemen Pendidikan, Remaja Rosdakarya: Bandung. George H. Bodnar. Williams. S. Hopwood (2003:1) Accounting Information Sistem. Edisi Keempat. Jakarta; Salemba Empat.

Mulyadi. 2008. Sistem Akuntansi. Edisi Ketiga, Cetakan 
Keempat. Jakarta: Salemba Empat.

Mardi. 2011. Sistem Informasi Akuntansi. Cetakan Pertama. Bogor; Ghalia Indonesia.

Nugroho widjadjanto (2001:4) Sistem Akuntansi. Edisi Ketiga, Cetakan Keempat. Jakarta: Salemba Empat.

Romney, Marshal B dan Paul John Steinbart. 2005. Accounting Information Sistem. $9^{\text {th }}$ Edition. Jakarta; Salemba Empat.

SUMBER: http://penas-fkmtsi-

makassar.blogspot.com/2010/0 5/penjelasanorganisasi_01.html

(C)2008 Kementerian Agama Republik Indonesia Pusat Informasi Keagamaan dan Kehumasan. 